\title{
Higher education leadership responses applied in two South African comprehensive universities during the COVID-19 pandemic: A critical discourse analysis
}

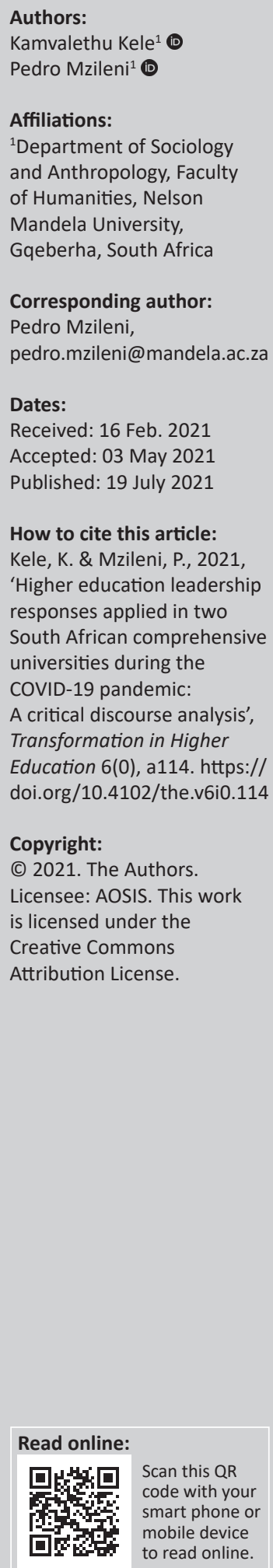

Background: This article explored the leadership responses that were used by two comprehensive universities in South Africa (Nelson Mandela University and University of Johannesburg) during the coronavirus disease 2019 (COVID-19) pandemic in continuing with the rolling out of their teaching and learning programmes safely and digitally under disruptive conditions.

Aim: Whilst universities in the developing world such as South Africa were expected to face challenges during the pandemic, this article showed that the leadership executives and general staff in two of its large universities, instead, crafted equitable and flexible improvisations to overcome the social challenges that could have posed a threat to their academic project.

Setting: The selection of these two specific universities provided a unique opportunity to engage with comprehensive, massified and post-merger former Technikon-university institutions that mainly cater for working-class students.

Methods: The social justice theory was utilised to frame the study, whilst critical narrative analysis was the methodology.

Results: This research reveals that South African comprehensive universities possess capacity to adapt and innovate in the middle of an institutional crisis using their flexible systems and agile personnel to drive the academy under such circumstances. The study also reveals that the process of social justice is full of contradictions. As the universities created equitable measures to assist underprivileged students, these measures also generated injustices for others.

Conclusion: This generated admirable and productive systematic traits to observe about some of our universities, as the South African higher education sector continued to engage with difficult conversations such as transformation.

Keywords: online learning; higher education transformation; leadership response; comprehensive universities; social justice; coronavirus disease 2019 (COVID-19).

\section{Introduction}

Universities located in the developing countries were largely expected to fail in the running of their learning and teaching responsibilities under the social conditions imposed by the coronavirus disease 2019 (COVID-19) pandemic (Salmi, Arnhold \& Basset 2020). In South Africa specifically, the focus of the higher education response to this issue emphasised the material inequalities that exist between historically white urban universities and historically black rural universities (Czerniewicz et al. 2020:961), with the former possessing the necessary technology and infrastructure to migrate its systems to the online space, whilst the latter was compelled to put its systems to a hold.

In this article, we want to reveal the leadership improvisations implemented by the other type of a university that is 'missing' from the conversation: the comprehensive university. South Africa has six comprehensive universities, ${ }^{1}$ but in this study, we will focus on two of them: Nelson Mandela University in Port Elizabeth and the University of Johannesburg in Gauteng.

We make the case that these two universities are located in the developing country, South Africa, and have a low- and middle-income student profile (Nelson Mandela University 2019:46; University of Johannesburg 2019:210) with teaching and learning systems that were underprepared

1.South Africa has six comprehensive universities, namely, (1) University of Johannesburg, (2) Nelson Mandela University, (3) Walter Sisulu University, (4) University of Zululand, (5) University of Venda and (6) University of South Africa. 
for the pandemic (Foxcroft ${ }^{2} \&$ Bosire $^{3}$ 2020; Marwala ${ }^{4}$ 2020a). Yet, their leadership structures in collaboration with student organisations and other stakeholders managed to frame equitable, socially just and innovative plans that largely accommodated their working-class students to overcome the challenges of the pandemic.

To breakdown this argument, the article has been divided into eight parts. Firstly, we define comprehensive universities in context. Secondly, we outline the study's theoretical concept. Thirdly, we state the case for our methodological approach. Fourthly, we critique how existing higher education literature frames equitable interventions in an environment of social deprivation and political crisis. The fifth part presents how Nelson Mandela University managed its teaching and learning affairs during the pandemic, whilst the sixth part looks at the University of Johannesburg's case. On the seventh part, we table a critical discussion of the findings and then conclude the article on the eighth part.

\section{Defining comprehensive universities in context}

Comprehensive universities can be generally defined as post-apartheid institutions of higher learning that are modelled around the following:

1. diversifying their academic programmes into an astute combination of short and distance learning programmes, vocational and skills training courses, higher certificates, diplomas and undergraduate and postgraduate qualifications (Department of Education [DoE] 2004:5)

2. they are post-2004/2005 multi-campus mergers between traditional universities, colleges, and former Technikons into being the contemporary comprehensive universities as we know them today (Nel 2007:2).

3. observing a public mandate to massify student enrolments for purposes of offering targeted skills training courses that are related to industry, particularly for students who come from working-class backgrounds (DoE 2004:4)

4. they are overwhelmed with major infrastructural shortfalls ranging from a lack of conducive student accommodation, lack of access to internet connectivity and updated library services amongst other basic services (Department of Higher Education and Training [DHET] 2014:6)

5. embracing innovative and flexible practices of learning, teaching and systematic leadership (Brink 2010:259)

6. preparing to adapt to rapid technological changes and requirements to optimise the employability of their graduates (Brink 2010:259)

7. having closer relations with both urban and ruraltownship communities and other external stakeholders, which 'localises' them as universities that are in service to society (DoE 2004:5).

2.Professor Cheryl Foxcroft is deputy vice chancellor: learning and teaching at Nelson Mandela University.

3.Dr Sam Bosire is a chief information technology officer at Nelson Mandela University. 4.Professor Tshilidzi Marwala is a vice chancellor at the University of Johannesburg.
We have selected the University of Johannesburg and Nelson Mandela University as case studies for this article because of their institutional similarities and for three other major reasons.

Firstly, their urban locations in the South African landscape and profile of their student bodies - this refers to their 'middleincome' status as city-based institutions that are made up of urban main campuses (Auckland Park Kingways campus for University of Johannesburg and Summerstrand campuses for Nelson Mandela University) and township campuses (Soweto campus in University of Johannesburg and Missionvale campus in Nelson Mandela University) and they have a growing enrollment of students from poor and working-class families (Nelson Mandela University 2019:46; University of Johannesburg 2019:210) who needed equitable material support from these two universities to (1) travel back to their homes when the pandemic began (Nelson Mandela University 2020a) and (2) be provided with devices by their universities to begin studying online during the pandemic (Foxcroft \& Bosire 2020; Marwala 2020a).

Secondly, their productive and proactive public engagement with COVID-19 - where they supported their local neighbouring communities and health institutions with protective equipment to fight the pandemic (Nelson Mandela University of Johannesburg 2020) and, as mentioned earlier, also formulated alternative ways of delivering teaching and learning processes during the pandemic for their students despite the generally limited resources in the higher education sector (DHET 2014:8).

Thirdly, their general appetite to redefine themselves as 'newgeneration' and 'dynamic' universities in Africa - where they seek to spearhead the country's social and innovative possibilities (Brink 2010:259; Fraser-Moleketi 2019:4).

We define 'leadership response' for this article's context as the collective effort applied by the university executive, middle management, lecturers and Heads of Departments, financial and support service administrators, technical staff such as security guards, cleaners, electricians, medical practitioners, COVID-19 screening and testing coordinators and volunteers, property maintenance officers, student leaders, trade union leaders, government officials and general students who all converged systematically and on an ad hoc basis, driven by a social justice ethos, to ensure that the 2020 academic year for these comprehensive universities was a 'success'. ${ }^{5}$

\section{Social justice theory and South African higher education}

The leading higher education studies scholars and practitioners in South Africa such as Badat (2009:459), Pityana (2010:39), Jansen (2017:1), Swartz (2015a:2) and Habib (2019:x) contextualise the concept of social justice as being the key instrument in the utilisation of the post-apartheid university for purposes of addressing poverty, underdevelopment and

5. Our notion of 'success' in this article refers to what the higher education sector has rather gained from the COVID-19 pandemic, which is systematic capabilities and rather gained from the COVID-19 pandemic, which is systematic capabilities and
flexible improvisations that many disadvantaged students and comprehensive universities displayed under tough conditions to complete the academic year. 
inequality. In this framework, South Africa is understood as a society with deep-seated patterns of socioeconomic inequality mainly categorised according to race, gender, class and geographic origin (Black, Spreen \& Vally 2020:41). To systematically and comprehensively address these challenges, equitable access to higher education and training for the poor is one of the progressive options advanced by the country's national consciousness (National Development Plan 2012:296).

It is on this basis that South African vice chancellors interviewed by Jansen (2017:xiii) have broadly supported the \#FeesMustFall movement's campaign for free education in principle (2017:222-228) despite their numerous disagreements with its tactics, which they deemed to be violently inhumane (Habib 2019:26) and infringing on other people's rights (Swartz 2015b). Keet, Sattarzadeh and Munene (2017:2) harmonised these differences by emphasising that 'violence is not a prerequisite for radicalism and militancy in the current South African context'. In other words, the social justice struggle can be advanced under contradictory conditions of a radical approach and/or sometimes in a peaceful, systematic, negotiated and consensus-generated method.

When South African comprehensive universities were faced with the COVID-19 pandemic that mainly posed a threat to the learning experiences of poorer students, they overwhelmingly made public commitments to do what was feasible at their disposal to equitably make their systems accessible to these students (Foxcroft \& Bosire 2020; Marwala 2020a; University of South Africa 2020; Walter Sisulu University 2020; University of Venda 2020; University of Zululand 2020). This mainly entailed providing technological gadgets (computers/laptops, data and study material) to poorer students for free, the flexible application of assessment deadlines to cater for those who might have connectivity breakdowns in their underdeveloped communities and applied socio-political pressure by student political organisations to secure the learning rights of disadvantaged students.

It is on these grounds that we argue that universities applied a social justice framework in operationalising their systems during the pandemic - where equitable, flexible and politically astute methods of accessibility to the university practices were enabled for underprivileged students to integrate and succeed within the genre of 'equal opportunities for all'.

\section{From \#FeesMustFall to COVID-19: Higher education and socio-political crisis}

South Africa's socioeconomic profile characterised by high levels of inequality, poverty and unemployment has filtered into the higher education landscape. The 2015/2016 free education protests emphasised this case. Students from poor communities, unable to pay university fees and also facing diminishing chances of obtaining employment in a crumbling economy, took to the streets and revolted against the unaffordability of higher education and the untransformed patterns of coloniality that still define the epistemic and sociocultural makeup of universities (Ndlovu-Gatsheni 2013, cited in Godsell \& Chikane 2016:59).

These protests although had macro- and micro-characteristics. Macro-characteristics were in the form of the struggle for the transformation of the country's political economy to begin prioritising the needs of the poor and the working class, such as public investment in free education and training to create a skilled workforce with better opportunities to make livelihoods (Bond 2016:196-198). Micro-characteristics were in the form of the day-to-day struggles that students faced in university campuses where they lacked access to basic needs such as food, transport, toiletries, clothing items, stationery and subsistence allowances to participate in student social life (Godsell \& Chikane 2016:60).

The micro-struggle is what we want to underscore in this article. From our experience, the everyday lives of poor students in universities tend to be overlooked in conversations about student protests. These conversations emphasise statistics, slogans and political statements, which tend to envelope poor students under a single talk of statistical averages. However, when the life of each poor student gets broken down into different pieces of stories and experiences, the conversation changes and begins to reveal the deepseated patterns of inhumanity and indignity that students endure as a result of being poor in urban universities.

For instance, the National Students Financial Aid Scheme (NSFAS) is widely known in South Africa for its administrative incompetence, which compels poor students in universities to live without access to food and other basic needs for at least half of their academic year (Habib 2019:64-65). As such, student political organisations organise protests in universities to fight for these basic needs by asking universities themselves to intervene in these challenges and provide food and basic needs to poor students (Jansen 2017:172). It is on this score that Nelson Mandela University institutionalised a food feeding scheme as part of its annual budget programme to cater for the food shortages that its poor students endure as a result of state failure to administrate financial aid efficiently and on time as per the academic calendar (Nelson Mandela University 2019:48).

The shifting of university responsibilities in this instance towards the constant provision of food to poor students has generated criticism from some practitioners in the higher education sector. Jansen (2017:172) is concerned that the South African university has become a 'welfare university' where the core function of quality and internationally competitive research, teaching, learning and engagement has been compromised in favour of food aids for poor students - a function that should have been performed by the state. Jansen (2017:174-176) goes further to argue that students themselves have come to be entitled to these benefits as although they are an expected function of the university - similar to the government functions of providing social grants to the older members of the families where these students come from. 
In our view, the framing of providing poor students with food aid as being a shift to a 'welfare university' is not a neutral observation. It is informed by a single orientation of understanding what a university is and its purpose, which is an orientation of a Western university in the case of Jansen. The Western university derives its value, purpose and sustainability from undertaking research that is globally relevant to attract prestige and generate revenue subsidies, endorsements and competitive student fees from international students (Ginsberg 2011:81-82). Without these economic assets, the university would be unable to maintain its credibility, relevance and prestige and could possibly collapse. Vice chancellors of top South African universities such as Wits University (Habib 2019:ix-x) and University of Cape Town (Phakeng 2019) have also publicly endorsed such positions, arguing that their universities seek to participate in this 'global research prestige' contest to keep their universities competitive.

Our critique towards these viewpoints is based on four observations. Firstly, our understanding is that there are many different kinds of universities and their purposes, depending on the context of such institutions. Many different parts of the world are experimenting with agricultural universities (Nieuwenhuis, Verhaar \& Hoeve 2003:171) and medical universities (Pepeta 2019) with a purpose of servicing their local communities and societies as public institutions. The notion of a Western university concerned about abstract research that has a universal appeal for revenue generating purposes is but a single model of a university that is not preferred in other societies. In this instance, other universities located in other societies favour a 'down-to-earth' approach where they do not only theorise people's challenges but are also placed in context to serve humanity and their local communities (Van Rooy 2003:xiii). In this regard, South Africa can also generate from its own context and define its own model of a public university that would be best suited to service its society that is mainly faced with challenges of poverty and unemployment.

Secondly, the notion of a 'welfare university' grossly minimises the socioeconomic legacy of the (post)apartheid system, its generational impact and its intersectional reach. Colonialism dispossessed and displaced the entire African family. The poverty wages earned by adult workers in the untransformed economy of South Africa that still resembles apartheid wage scales is replicated by the student's inability to pay for their basic needs in university (Satgar 2016:222). A South African university that exists out of these social challenges ought to be redesigned to prepare itself to enrol students with such challenges and avail social support services to integrate such students into its university life.

Thirdly, the 'welfare university' thesis fails to comprehend what the decolonisation argument tabled by students seeks to achieve. One of the significant legacies of colonialism is the proletarianisation of Black people and their communities to the extent where they cannot cater for their basic needs (Hendricks, Ntsebeza \& Helliker 2013:3-4). In this instance, the theory of decolonisation entails a fight for both macro- and micro- dividends of a political breakthrough, which are (1) the right to own land, wealth, identity and self-determine (macro) and (2) also the right to dignity, employment, food, water, housing and social welfare (micro). In other words, a decolonised society would be to live in a social reality that has all the characteristics of colonialism dismantled. Part of this social transformation attempt entails the work carried out by universities during the COVID-19 pandemic to make equitable measures to accommodate and support underprivileged students with basic needs. This article adds to the conversation by tabling how comprehensive universities improvised their systems to support these challenged yet resilient students.

Finally, the COVID-19 pandemic in South Africa demonstrated how a public university located in South Africa is supposed to shape itself. South African conditions call for a social justice-oriented university that must (1) produce research for humanity (the production of COVID-19 protective equipment, sanitisers and vaccine research for the country's public healthcare strategy is a case in point) and (2) be driven by the ethos of Ubuntu (Masitera 2020:6) and provide welfare for vulnerable students in the form of food, transport, laptops, data and flexible learning and teaching programmes to achieve equitable access to higher education.

In this regard, the South African university must redefine itself to be an active agent in service of humanity to dismantle social inequalities through an equitable provision of university services. These attributes of a university anchored on social justice demonstrate that being a university that is in service of society does not necessarily have to come at the expense of research excellence. Instead, being a people-centred university that is in service to society should be viewed as a prerequisite for research excellence and institutional sustainability - where we get to possess, as Mamdani (2009:215-216) proposed, African public universities that will produce knowledge to address the unique challenges of our continent.

\section{Methodological note}

A critical narrative analysis was utilised to conduct the study. This critical analysis involved the reading and interpretation of textual data from newspaper commentary and the decision statements taken and published by these two universities under study (McAlpine 2016:33). We also used our own personal experiences from working and studying directly in one of these universities, at Nelson Mandela University. Our intimate experiences of working and studying at Nelson Mandela University during the pandemic were used as a source of data generation, analysis (McAlpine 2016:34-35) and triangulation (Holtzhausen 2001).

The COVID-19 crisis was extensively covered in newspaper commentary given its widespread effects on every community as a communicable disease (Park et al. 2020, cited in Hess \& Waller 2021:22). It then becomes obvious as to why the media was one of the useful sources to analyse the pandemic. In addition, media coverage of the pandemic carried a heavier form of government oversight, where 
public content about the pandemic had to be carried out accurately to keep the citizenry armed with valuable and coordinated information as an attempt to minimise misinformation (Eck \& Hatz 2020:603) - as one higher education practitioner stated:

[T]he Covid-19 pandemic remains a communicable disease that can be defeated through collaborative strategies ... it will be the spirit of sacrifice, self-discipline, information sharing, and collective consciousness that will see our society overcome this period. (Jack 2020 para. 2)

Newspaper articles as research tools have been widely commended in the social sciences mainly for their investigative, brief, flexible and first-hand information reporting and analysis of complex events (Waldman 2004:7172). In addition, as the digitalisation of information and the rise of the smartphone industry accelerated, the public space of news reporting has been democratised as individual citizens are able to publish material from their gadgets without the institutional regulations of traditional media houses (Obi-Ani, Anikwenze \& Isiani 2020:1). What we have also observed although during the course of this study is that the traditional news agencies themselves have also reconfigured their operations by tapping into the social media space to distribute information.

The period of the COVID-19 pandemic saw these flexibilities in information sharing productively converging at the benefit of readers and researchers. Our methodological engagement although with these pieces of data - newspaper articles and university statements - was both 'empathetic and critical' (Jansen 2017:xiii). Put differently, we appreciated the convenient availability of information, whilst at the same time putting the same information under close scrutiny and critique guided by our social justice orientation.

\section{Nelson Mandela University: Equitable learning pathways}

Nelson Mandela University used public statements and opinion pieces written by its senior executive members on nationwide online newspaper platforms to communicate its COVID-19 teaching and learning measures to students, staff and the public. Its communication patterns covered two aspects: (1) the ethos and value system driving its COVID-19 teaching and learning measures and (2) the improvisations taken in collaboration with all relevant stakeholders to continue with the teaching and learning project through digital platforms.

On the ethos and value system of the University in applying equitable and socially just measures to continue with studies online:

A 'one-size-fits-all' approach, such as only adopting online learning to complete the first semester, would exclude many of our students. Given our strong commitment to social justice and equality, this is not an acceptable option for us, hence we have developed two learning and teaching pathways (and variations of these) to enable our students to complete their first semester modules and the academic year. (Jack 2020: para. 2)
The University then applied the following strategy to amend its teaching and learning programme to suit students who might have been affected by the pandemic:

Many of our students live in the townships, informal settlements and rural areas where they do not have online access or a private space to study. We estimate that about $55 \%$ of our students have laptops and connectivity and a further $10 \%$ could learn via their smartphones. This means that about $35 \%$ of our students are currently not able to participate in digital learning and teaching off campus ... The pathways range from digital to face-to-face when classes resume, to a blended approach which are combinations of the two. Navigating them will take collective, ongoing effort from the university to care for and support our students and staff. We have consulted our staff and students and colleagues at other universities in South Africa and internationally and we have studied a wider range of articles on teaching during times of disruption. We are now in the preparation phase and the pathways will start on 28 April. (Foxcroft \& Bosire 2020 para. 11)

Pathway 1 consisted of digital teaching and learning methods, which took place from April 28, and underprivileged students were provided with monthly 20GB data and laptops to participate. Pathway 2 students were scheduled to receive face-to-face classes under COVID-19 regulations later in the year. The student counselling service of the university switched its services to a $24 / 7$ online interface to provide social support for the challenging conditions. The university also provided training to its teaching staff to manage digital migration including devices and data for them to work from their homes. Digital training was also provided for frontline technical staff to operate their securitisation, cleaning, communication and maintenance services under carefully observed COVID-19 regulations - mask-to-mask interaction, social distancing, regular sanitising and screening.

\section{University of Johannesburg: Commitment to innovation and stakeholder engagement}

The University of Johannesburg also utilised its official website and online public newspaper platforms to communicate with students, staff and the general public during the pandemic. The university's framework to continue with classes under COVID-19 conditions was driven by two aspects: (1) a pedagogy of care for its students and (2) its reliance on stakeholder engagement and 'technological traditions'.

\section{On the university's ethos of care:}

There were several uncertainties, and the threats loomed large ... the odds seemed heavily stacked against the university, more so when UJ has many first-generation and international students, many of whom live in university-owned student residences or private accommodation ... for many of them, returning home was simply not an option. Physical distancing was required, but more than ever before, social solidarity was needed ... Whatever the decision, the safety and wellbeing of our students took priority over other considerations ... our goal was that the academic year must not be lost and that, in our approach, no student should be left behind. (Parekh ${ }^{6} \&$ Sinha $^{7} 2020$ para. 3)

6.Professor Angina Parekh is a deputy vice chancellor: academic at the University of Johannesburg.

7.Professor Saurabh Sinha is a deputy vice chancellor: research and internationalisation at the University of Johannesburg. 
The university's prior investment on technology and stakeholder accord made its coping mechanisms with COVID-19 manageable:

As South Africa's reality is one of inequality, it was vital that we recognise our vulnerabilities. More than ever before, we required innovation and collaboration. In this regard, our teaching, research, internationalisation strategy and trajectory proved indispensable. (Parekh \& Sinha 2020 para. 6)

I wish to thank the representations made by the Interim SRC regarding online teaching and learning. As a University that embraces inclusivity, I am pleased to announce that the President and Secretary-General of the Interim SRC are invited to the Covid-19 Coordination Committee online meetings, as full members of the committee. I also reiterate my gratitude to the tremendous work that is being done by our academic and support staff in recent weeks, who have worked tirelessly to ensure that our operations continue uninterrupted. Special thanks to our academic and administrative staff for their efforts to ensure that our transition to online learning and teaching is as seamless as possible. (Marwala 2020a para. 10)

In 2018, when I took over the reins as vice-chancellor and principal of the University of Johannesburg (UJ), I embarked on a journey to position the university at the forefront of the fourth industrial revolution (4IR). The goal of UJ is to foster a platform for innovative and ground-breaking research to produce graduates who are agile and curious and able to be active participants in a technology-driven and digital environment. (Marwala 2020b:2)

A newspaper report also revealed that Marwala announced that the university's online attendance superseded physical attendance and that undergraduate success rate was $86.3 \%$ compared with $84.7 \%$ of the previous year (Pretoria News 2020).

Marwala later shared these statistics on Twitter to spark the debate (Figure 1).

\section{Discussion}

The leadership responses applied by Nelson Mandela University and University of Johannesburg ranged between numerous forms of equitable care and flexible management of their systems. A modern university, generally, is known for its rigid systems of certainty and predictability that are tailored around an academic year. These systems are determined a year before their scheduled implementation. This involves university teaching timetables, examination dates, graduation periods, planned enrolments and research seasons for sabbaticals, visiting scholars, thesis defences and annual conferences. Added to these systemic certainties are the middle-class sensibilities that universities operate under where students are expected to have cash flow with them to participate in the urban daily life of a university (Godsell \& Chikane 2016:60) - commuting to attend classes and library activities, visiting coffee shops and restaurants for peer interaction, and going out to night evening, book launches and career expos for social networking (Jansen 2017:180).

8.Student representative council (SRC) carries the student's voice to university committees. The SRCs in South Africa are generally made up of different student political organisations.
Tshilidzi Marwala

ate @txm1971

UJ is has now started the second semester. The success rates for the first semester is $86.3 \%$ compared to $84.7 \%$ last year. Class attendance was higher this year than last year. Student cancellations were lower this year than last year. Does this mean online learning is better?

9:14 AM · Jul 28, 2020 from Johannesburg, South Africa. Twitter for iPhone
806
148
2,908

Source: Marwala, T 2020c, UU is has now started the second semester: The success rates for the first semester is $86.3 \%$ compared to $84.7 \%$ [Tweet], viewed 10 June 2021, from https:// twitter.com/txm1971/status/1288009976183771136

FIGURE 1: University of Johannesburg's vice chancellor using social media, Twitter, to communicate COVID-19 learning and teaching successes with students, staff and the general public to generate open debate.

The COVID-19 pandemic disrupted all these traditional arrangements of operationalising a university system in two ways: (1) the lockdown period in South Africa between March and June 2020 resulted in the cancellation of many traditional university ceremonies and events such as graduations. The academic year was also extended into 2021 and (2) universities realised that poorer students are at an extremely vulnerable position than ever before and social measures had to be made quickly to provide basic needs for them such as food allowances, counselling services, data and laptops. These are equitable measures that these universities have not taken before. Previously, a threat to a traditional layout of a university academic calendar year posed a potential collapse to the university system (Habib 2019:50). However, the COVID-19 pandemic necessitated that universities dig further into their social justice orientation and recognise the potential of the university system to exclude especially when it is aided by the social conditions of the pandemic. As a result, we witnessed flexible forms of assessment being applied wherein (1) students were given many opportunities to resubmit their assessments, (2) they interfaced with lecturers over social mediums such as WhatsApp and telephone calls for consultation purposes and (3) university administrative systems adjusted their registration, examination, fees payment, graduation and marks completion dates to accommodate all possible setbacks imparted by the pandemic.

Although these leadership improvisations were equitably applied by universities, they were not without their fair share of challenges and injustices. In some instances, Nelson Mandela University and University of Johannesburg were also complicit in driving institutional 
exclusion by overemphasising their macro-achievements and underemphasising the micro-experiences of students during the pandemic. These contradictions, as Keet et al. (2017:2) indicated, are part and parcel of the 'messiness' of the efforts towards attaining social justice. In other words, the inequality climate of South Africa entangles social transformation in a constant battle of reproducing other injustices as it tries to resolve others.

Fairly, both universities provided equitable provisions under the challenging conditions, but they also displayed other layers of unfairness. At Nelson Mandela University, where we are based, the planned concept of Pathway 1 and Pathway 2 did not get implemented as planned. The COVID-19 lockdown measures in South Africa continued for the whole of year and this made it impossible for the second group of students to return to the university campus for face-to-face classes. As a result, they had to also form part of the Pathway 1 group and operate on similar online conditions. This created a challenging working environment for lecturers and administrators, resulting in the academic year to carry on until April 2021. At the time of writing this article, the Nelson Mandela University was facing student protests over the registration irregularities for the 2021 academic year, outstanding examination results from the 2020 academic year and the lack of food allowances to students by NSFAS and the University's scholarship scheme (Nelson Mandela University 2021).

For the University of Johannesburg, their leading student political organisation, the Economic Freedom Fighters Student Command (EFF SC), issued a public statement on their Facebook account criticising the university and its vice chancellor for not catering for the needs of all poor students and for also using social media to censure comments from students who publicly disagree with him:

\footnotetext{
We have sent numerous communications to the University pleading with them to suspend online learning during the lockdown period until the demands contemplated above [in the previous page of their statement] have been implemented however the University continued to ignore the submission made and went ahead to implement online learning ... the VC went further to pull media stunts on Twitter and Facebook ... deleting our comments from his posts ... we further submit to UJ students finance to pay nsfas allowances to all students who have not received their allowances. Currently, there are students who still have not received their NSFAS allowances since February, which is very much unacceptable and we call for a rectification on this matter AS SOON AS POSSIBLE. (EFF SC University of Johannesburg 2020)
}

In essence, the leadership improvisations driven by these universities might have been eloquently communicated in public newspapers and social media by their executives as being progressive, equitable, flexible, and socially just, but it is equally important to triangulate such perspectives with personal experiences and other people's everyday encounters to generate a critical conversation. Both universities registered commendable and agile leadership styles during the pandemic, but they also generated numerous injustices that emanate from the structural obstacles that the comprehensive universities in South Africa are faced with.

\section{Concluding observations}

Essentially, this study has revealed that beyond the usually dominant and extreme comparisons between privileged white research universities and poor black teaching universities, there is another layer of universities in the sector that should receive scholarly attention in order for us to critically understand the post-apartheid higher education trajectory and its potential. The comprehensive universities analysed in this study have demonstrated that they do possess management and leadership assets to navigate crisis and innovate for purposes of realising a socially just higher education experience for their underprivileged students. It is these narratives of institutional creativity and perseverance that should also get more research attention alongside other emerging discourses in higher education studies such as transformation, decolonisation and Africanisation. The diversification of studying all kinds of universities and their various experiences and practices would broaden our tools of comprehension and language to better understand and theorise the social experiment of our post-apartheid higher education landscape.

\section{Acknowledgements}

The authors would like to gratefully thank the academics and students in the Department of Sociology and Anthropology in Nelson Mandela University for the critical comments made to this study at its preliminary stages when it was publicly presented at the postgraduate research colloquium hosted in the Department on 27-28 October 2020.

\section{Competing interests}

The authors have declared that no competing interests exist.

\section{Authors' contributions}

K.K. conducted the literature study and presented the study as an honour article. P.M. was the supervisor and assisted with the literature study, guided data interpretation and then wrote the journal article.

\section{Ethical considerations}

This article followed all ethical standards for a research without direct contact with human or animal subjects.

\section{Funding information}

This research received no specific grant from any funding agency in the public, commercial or not-for-profit sectors. 


\section{Data availability}

Data used for this study are publicly available on the University's communication platforms and newspapers.

\section{Disclaimer}

The views, opinions, findings and recommendations expressed in this article are those of the authors and do not reflect the policy or position of affiliated agencies of the authors.

\section{References}

Badat, S., 2009, 'Theorising institutional change: Post-1994 South African higher education', Studies in Higher Education 34(4), 455-467. https://doi.org/10.1080/ 03075070902772026

Black, S., Spreen, C.A. \& Vally, S., 2020, 'Education, Covid-19 and care: Social inequality and social relations of value in South Africa and the United States', Southern African Review of Education 26(1), 40-61.

Bond, P., 2016, 'To win free education, fossilised neoliberalism must fall', in S. Booysen (ed.), Fees must fall: Student revolt, decolonisation and governance in South Africa, pp. 192-213, Wits University Press, Johannesburg.

Brink, E., 2010, The university for a new generation, Division for Institutional Advancement: University of Johannesburg, Johannesburg.

Czerniewicz, L., Agherdien, N., Badenhorst, J., Belluigi, D., Chambers, T., Chili, M. et al., 2020, 'A wake-up call: Equity, inequality and Covid-19 emergency remote teaching and learning', Postdigital Science and Education 2(0), 946-967. https://doi. org/10.1007/s42438-020-00187-4

DoE, 2004, Creating comprehensive Universities in South Africa: A concept document Government of South Africa, Pretoria.

DHET, 2014, Building higher education: Infrastructure renewal, revitilisation, and development, Government of South Africa, Pretoria.

Eck, K. \& Hatz, S., 2020, 'State surveillance and the COVID-19 crisis', Journal of Human Rights 19(5), 603-612. https://doi.org/10.1080/14754835.2020.181 6163

EFF SC University of Johannesburg, 2020, UJ APK EFF student command statement on UJ's management failure to respond to 21 demands to e-learning, viewed 17 April 2021, from https://www.facebook.com/UJ-APK-EFF-Studentcommand-272883529574218/photos/pcb.1342370495958844/13423703826 25522 .

Foxcroft, C. \& Bosire, S., 2020, Nelson Mandela University's conundrum - Online teaching when 35\% of students don't have digital access, Daily Maverick, viewed 14 April 2021, from https://www.dailymaverick.co.za/article/2020-04-23-nelsonmandela-universitys-conundrum-online-teaching-when-35-of-students-donthave-digital-access/.

Fraser-Moleketi, G., 2019, Chancellor's graduation address, ceremony 1, Faculty of Arts, Faculty of Law, Nelson Mandela University, Port Elizabeth.

Ginsberg, B., 2011, The fall of the faculty: The rise of the all-administrative university and why it matters, Oxford University Press, New York, NY.

Godsell, G. \& Chikane, R., 2016, 'The roots of the revolution', in S. Booysen (ed.), Fees must fall: Student revolt decolonisation and governance in South Africa, pp. 54-73, Wits University Press, Johannesburg.

Habib, A., 2019, Rebels and rage: Reflecting on \#FeesMustFall, Jonathan Ball Publishers, Johannesburg.

Hendricks, F., Ntsebeza, L. \& Helliker, K., 2013, 'Land question in South Africa', in F. Hendricks, L. Ntsebeza \& K. Helliker (eds.), The promise of land: Undoing a century of dispossession in South Africa, pp. 1-28, Jacana Media, Auckland Park.

Hess, K. \& Waller, L.J., 2021, 'Local newspapers and coronavirus: Conceptualising connections, comparisons and cures', Media International Australia 178(1), 21-35. https://doi.org/10.1177/1329878X20956455

Holtzhausen, S., 2001, 'Triangulation as a powerful tool to strengthen the qualitative research design: The Resource-based Learning Career Preparation Programme (RBLCPP) as a case study', Presented at the Highe Education Close Up Conference 2, Lancaster University, 16th-18th July 2001 viewed 09 April 2021, from http://www.leeds.ac.uk/educol/documents/ 00001759.htm.

Jack, L., 2020, 'The core value of Ubuntu in our praxis to navigate the COVID-19 pandemic', Discourse of Student Life 2(7), viewed 08 April 2021, from https:// studentaffairs.mandela.ac.za/Discourse-of-Student-Life/August-2020-(1)/Thecore-value-of-Ubuntu-in-our-praxis-to-navigate.

Jansen, J., 2017, As by fire: The end of the South African University, Tafelberg Publishers, Cape Town.

Keet, A., Sattarzadeh, S.D. \& Munene, A., 2017, 'An awkward, uneasy (de)coloniality higher education and knowledge otherwise', Education as Change 21(1), 1-12. https://doi.org/10.17159/1947-9417/2017/2741

Mamdani, M., 2009, Scholars in the marketplace: The dilemmas of neo-liberal reform at Makerere University 1989-2005, HSRC Press, Johannesburg.
Marwala, T., 2020a, COVID-19 update 08, Dear UJ Community, University of Johannesburg Media Releases, viewed 14 April 2021, from https://www.uj.ac.za/ newandevents/Pages/COVID-19-UPDATE-08.aspx.

Marwala, T., 2020b, Closing the gap: The fourth industrial revolution in Africa, Pan Macmillian, Johannesburg.

Marwala, T, 2020c, UJ is has now started the second semester: The success rates for the first semester is $86.3 \%$ compared to $84.7 \%$ [Tweet], viewed 10 June 2021, from https://twitter.com/txm1971/status/1288009976183771136

Masitera, E., 2020, 'Towards a humane community: The search for disability justice in higher education through African moral thinking', Transformation in Higher Education 5(0), a85. https://doi.org/10.4102/the.v5i0.85

McAlpine, L., 2016, 'Why might you use narrative methodology? A story about narrative', Estonian Journal of Education 4(1), 32-57. https://doi.org/10.12697/ eha.2016.4.1.02b

National Development Plan, 2012, Our future - Make it work, Vision 2030 Nationa Development Plan, National Planning Commission, Pretoria.

Ndlovu-Gatsheni, S., 2013, 'Decolonising the university in Africa', The Thinker 5(2), $46-51$.

Nel, H., 2007, 'Enhancing the student experience in a merged multi-campus university in South Africa', Paper presented at the Annual Conference of the Society for Research into Higher Education, December 2007, Nelson Mandela University, Port Elizabeth.

Nelson Mandela University, 2019, Integrated annual report 2019, viewed 14 April 2021, from https://publications.mandela.ac.za/publications/media/ Store/documents/Annual\%20Reports/88-Annual-Report-2019.pdf.

Nelson Mandela University, 2020a, Mandela University students head home, viewed 15 April 2021, from https://news.mandela.ac.za/News/Mandela-Universitystudents-head-home.

Nelson Mandela University, 2020b, Mandela University plays its part in the fight against COVID-19, viewed 15 April 2021, from https://www.mandela.ac.za/ News-and-Events/Coronavirus-Information/COVID-19-Memos/MandelaUniversity-plays-its-part-in-the-fight-aga.

Nelson Mandela University, 2021, Nelson Mandela University registration update viewed 17 April 2021, from https://news.mandela.ac.za/News/NelsonMandela-University-Registration-Update.

Nieuwenhuis, L., Verhaar, K. \& Hoeve, A., 2003, 'Networking between economy and education: Regional 'knowledge transfer in Dutch agriculture', in R. Rutten, F. Boekema \& E. Kuijpers (eds.), Economic geography of higher education: Knowledge infrastructure and learning regions, pp. 171-185, Routledge, London.

Obi-Ani, N., Anikwenze, C. \& Isiani, M.C., 2020, 'Social media and the Covid-19 pandemic: Observations from Nigeria', Cogent Arts \& Humanities 7(1), 1-15. https://doi.org/10.1080/23311983.2020.1799483

Parekh, A. \& Sinha, S., 2020, UJ's top executives explains how the Institution steered the 2020 academic year, viewed 16 April 2021, from https://www.uj.ac.za/ newandevents/Pages/UJs-top-executives-explains-how-the-Institution-steeredthe-2020-academic-year.aspx.

Park, S., Fisher, C., Lee, J.Y., McGuinness, K., Sang, Y., O’Neil, M. et al., 2020, ‘Digital news report: Australia 2020', News and Media Research Centre, University of Canberra, viewed 09 April 2021, from https://apo.org.au/node/305057.

Pepeta, L., 2019, 'New medical school to open in 2021', Mail and Guardian, viewed 17 April 2021 from https://mg.co.za/article/2019-10-18-00-new-medicalschool-to-open-in-2021/.

Phakeng, M., 2019, 'UCT leaps up in world rankings', UCT News, viewed 17 Apri 2021, from https://www.news.uct.ac.za/article/-2019-09-12-uct-leaps-up-inworld-rankings.

Pityana, B.N., 2010, Higher education, transformation and Africanisation - A paradigm shift? Study South Africa: The Guide to South African Higher Education 9th Edition International Education Association of South Africa viewed 07 April 2021, from http://studysa.org/wp-content/uploads/2019/03/ Study-SA-9th-edition.pdf.

Pretoria News, 2020, Blending learning in the COVID-19 era: UJ's agility in the 4IR space, Pretoria News, 05 August 2020, p. 4.

Salmi, J., Arnhold, N. \& Basset, R.M., 2020, The Big Bad Wolf moves south: How COVID-19 affects higher education financing in developing countries, World Bank Blogs, Education for Global Development, viewed 13 April 2021, from https://blogs.worldbank.org/education/big-bad-wolf-moves-south-how-covid19-affects-higher-education-financing-developing.

Satgar, V., 2016, 'Bringing class back in: Against outsourcing during \#FeesMustFall at Wits', in S. Booysen (ed.), Fees must fall: Student revolt, decolonisation and governance in South Africa, pp. 214-234, Wits University Press, Johannesburg.

Swartz, D., 2015a, Vice-Chancellor's Report to Council, Fourth Quarter Review: 2015, Nelson Mandela University, Port Elizabeth.

Swartz, D., 2015b, Vice-Chancellor's communique to students and staff, 23 October 2015, Nelson Mandela University, Port Elizabeth, viewed 07 April 2021, from https://www.facebook.com/MandelaUni/posts/984405631611170.

University of Johannesburg, 2019, University of Johannesburg annual report 2019 viewed 14 April 2021, from https://www.uj.ac.za/about/Documents/Annual\%20 reports/UJ_AnnualReport2019.pdf.

University of Johannesburg, 2020, UJ creates open-source, cheap ventilators as COVID-19 cases rise, viewed 15 April 2021, from https://www.uj.ac.za/
newandevents/Pages/UJ-creates-open-source-cheap-ventilators-as-COVID-19newandevents/
cases-rise.aspx. 
University of South Africa, 2020, Delivery of laptops to NSFAS students, viewed 10 June 2021, from https://www.unisa.ac.za/sites/myunisa/default/Anno uncements/Delivery-of-laptops-to-NSFAS-students.

University of South Africa, 2020b, Communique to students on the changes being made as a result of the Covid-19 lockdown, viewed 14 April 2021, from https:// www.unisa.ac.za/sites/myunisa/default/Announcements/Communique-tostudents-on-the-changes-being-made-as-a-result-of-the-Covid $\%$ E2 $\% 80 \% 9319$ lockdown.

University of Venda, 2020, Dr Nthambeleni affirms Univen's preparedness for the return of some students amid COVID-19, viewed 14 April 2021, from https:// www.univen.ac.za/news/dr-nthambeleni-affirms-univens-preparedness-forthe-return-of-some-students-amid-covid-19/.
University of Zululand, 2020, Distribution of laptops, viewed 14 April 2021, from http://www.unizulu.ac.za/distribution-of-laptops/.

Van Rooy, Y., 2003, 'Foreword', in R. Rutten, F. Boekema, \& E. Kuijpers (eds.) Economic geography of higher education: Knowledge infrastructure and learning regions, pp. xii-xiv, Routledge, London.

Waldman, M., 2004, 'International newspapers and research', The Serials Librarian 45(4), 71-80. https://doi.org/10.1300/J123v45n04_06

Walter Sisulu University, 2020, WSU invests R98 million in remote learning programme, viewed 14 April 2021, from https://www.wsu.ac.za/index.php/component/ content/article/286-wsu-newsletter/296-wsu-invests-r98-million-in-remotelearning-programme? Itemid $=437$. 